\title{
福建省産鳥竜茶の香気成分
}

福建農学院園芸系茶葉研究室

呉秋儿

農林水産省野菜・茶業試験場茶利用加工部

堀田博

\section{Comparison of Flavor Components of Fujian Oolong Teas}

\author{
Wu QIUER
}

Tea Speciality, Department of Horticulture, Fujian Agricultural College.

Hiroshi HORITA

National Research Institute of Vegetables, Ornamental Plants and Tea.

\section{1 緒言}

鳥竜茶は中国の六大名茶（緑茶，鳥竜茶，白茶， 黄茶, 黒茶, 紅茶) の一つであり, その主な生産地 は福建省，広東省と台湾である。

鳥竜茶は強い香りと柔らかな味を持ち，その特有 な香味により，中国だけでなく海外の消費者にも好 まれている。その中で, 福建省産の烏竜茶は高い品 質を持ち，生産量も多く，日本や東南アジアの国々 でも有名であり，その販売量も多い。近年，福建省 産の輸出用鳥竜茶の需要は飛躍的に増加し，その評 価も大変高く，福建省産品の中で最も有名な商品の 一っとなったが，その上らに高い評価が得られるの は，自然の花のよらな特有なエレガントな香りと甘 い柔らかな味を持っているだめである。

しかしながら，中国国内では，烏竜茶の香りを構 成している成分やその品質の特徽に関する化学分析 による研究は，長い,間行われなかった。

最近, 日本の竹尾, 山西らは, 種々の鳥竜茶の香 気成分とその生成機構の研究をしたが，生産地間の 香りの特徵や香気成分含量の差異を論した報告は少 ない。

そこで著者らは，福建省産烏竜茶の香気について の研究を始め, 代表的な茶産地間, 南部及び北部の 製造法の異なった茶の間，そして一級品と二級品の 茶の間とさらにそれぞれの荒茶と仕上げ茶の間の香 気成分含量の違いについて比較研究を行った。

\section{2 実験材料と方法}

\section{1 材料}

鳥竜茶は, 次の 6 種類の南部及び北部の福建省の 茶生産地上り取り寄せた。安溪鉄観音茶の一級品, 永春水仙茶の一級品及び二級品とそれぞれの荒茶と 仕上げ茶, 建歐水仙茶の一級品を試料とした。

\section{2 香気濃縮物の調整法}

連続水蒸気蒸留エーテル抽出法により調整し, 蒸 留は 1 時間行った。香気成分を含むエーテルは無水 硫酸ナトリウムで脱水し，濃縮して香気濃縮物（精 油）を得，秤量して精油量とした。

\section{3 香気成分の分析}

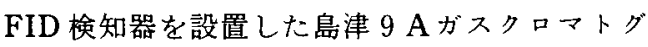
ラフ（GC）を使用し，担体にChromosorb，液相 としてPEG-20 Mをコートしたガラスカラム（内 径 $3 \mathrm{~mm} \times$ 長さ $3 \mathrm{~m}$ ) を用い，カラム温度は $60^{\circ} \mathrm{C}$ ら $190^{\circ} \mathrm{C}$ ず， $2{ }^{\circ} \mathrm{C} /$ 分の速度で昇温し，キャリアー ガスは窒素, $20 \mathrm{~m} l /$ 分の流速の条件で分析を行った。 島津 C-R 2 Aインテグレータにより各成分のピー ク面積を計算した。

各成分の同定は，標品とのガスクロマトグラフー 質量分析計によるマススペクトルの一致及びリテン ション值（リナロールのリテンション時間を 1 とし て計算した値）の一致により行った。 


\section{3 実験結果と考察}

6 種類の福建省産烏竜茶の香気成分の分析結果を 表に示す。值は全精油量と分析した全ピーク面積に 対するパーセント（面積百分率）の積で示した。同 一成分間の比較が出来る絶対量となっている。

同定された香気成分の中で，代表的な 30 の成分 について分析を行った。表中の 15 番以降嵪沸点 成分で，鳥竜茶香気の主な構成成分である。これら の成分の特敨は，様々な新鮮な花の香りを持ってい ることであり、これらが福建省産鳥竜茶の香気を形
成しているるのと思われる。

分析したこれらの香気成分含量は，生産地の異な った鳥竜茶の間では違って拈り，官能的には区別さ れる生産地による香りの違いが GC 分析によっても 裏付けられた。

\section{1 萎调方法の違いによる香気成分含量の变化}

福建省南部の萎调方法は擋拌萎调法, 北部では日 干萎调法を主体として，優れた烏竜茶が生産され， これらの萎调方法の違いによりそれぞれの特改が形 成されている。

南部の永春皮仙茶と安溪鉄観音茶, 北部の建颚水 表種々の福建省産烏竜茶の香気成分の比較

\begin{tabular}{|c|c|c|c|c|c|c|}
\hline \multirow{3}{*}{ 成 } & \multirow{2}{*}{\multicolumn{2}{|c|}{ 永 $\frac{\text { 春 }}{\text { 仕上げ茶 }}$}} & \multirow{3}{*}{$\frac{\text { 水 }}{\text { 荒 }}$} & \multirow{3}{*}{$\frac{\text { 茶 }}{\text { 茶 }}$} & \multirow{2}{*}{\multicolumn{2}{|c|}{ 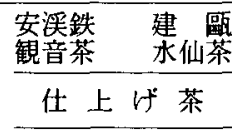 }} \\
\hline & & & & & & \\
\hline & 一級品 & 二級品 & & & 一級品 & 一䄲品 \\
\hline 1. 1ーペンテン-3ーオール & 40.9 & 36.4 & 20.0 & 38.1 & 96.4 & 66.5 \\
\hline 2. ペンタノール & 45.3 & 35.2 & 19.8 & 48.3 & 63.9 & 71.2 \\
\hline 3. テルピネン & 12.3 & 12.3 & 8.7 & 8.9 & 12.2 & 13.9 \\
\hline $\begin{array}{l}\text { 4. シスー2-ペンテンー1ーオール } \\
\text { 5. 2,5-ジメチルピラジン }\end{array}$ & 31.0 & 19.9 & 18.7 & 33.0 & 84.5 & 41.5 \\
\hline $\begin{array}{l}\text { 6. } 2,6 \text {-ジメチルピラジン } \\
\text { 7. シスー3-ヘキセニルアセテート }\end{array}$ & - & - & 26.0 & 7.5 & 16.5 & 33.7 \\
\hline 8. 6-メチル-5-ヘプテン-2-オン & 38.8 & 19.1 & 19.1 & 28.0 & 31.6 & 27.6 \\
\hline 9. シスー3-ヘキャンー1ーオール & 9.2 & - & 33.3 & 8.8 & 8.6 & 4.6 \\
\hline 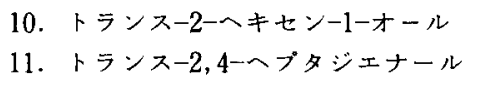 & 41.8 & 40.2 & 47.3 & 24.3 & 30.1 & 44.1 \\
\hline $\begin{array}{l}\text { 12. 1ーオクテン-3-オール } \\
\text { 13. リナロールオキサイド I }\end{array}$ & 78.1 & 68.3 & 57.9 & 27.6 & 41.2 & 46.7 \\
\hline 14. ベンズフルデヒド & 32.0 & 28.7 & 48.6 & 25.1 & 33.5 & 29.2 \\
\hline 15.リナロール & 105.6 & 74.4 & 63.5 & 101.5 & 159.7 & 102.3 \\
\hline 16. フェニルアセトアルデヒド & 121.3 & 121.4 & 108.8 & 65.5 & 170.4 & 112.8 \\
\hline 17. シスー3ーへキセニルへキサノェート & - & - & 21.2 & 24.9 & 15.0 & 19.8 \\
\hline 18. $\alpha$-テルピネオール & 50.8 & 47.9 & 68.8 & 43.8 & 43.9 & 63.1 \\
\hline 19. ベンジルアセテート & 58.0 & 39.7 & 67.8 & 33.9 & 56.5 & 49.8 \\
\hline 20. ファルネッセン & 75.5 & 87.2 & 100.0 & 87.7 & 79.4 & 90.7 \\
\hline 21. メチルサリチレート & 30.1 & 38.4 & 38.9 & 11.1 & 14.9 & - \\
\hline 22. ゲラニオール & 93.6 & 76.0 & 138.2 & 90.2 & 105.2 & 130.1 \\
\hline 23. ベンジルアルコール & 58.5 & 45.9 & 68.6 & 53.0 & 71.1 & 139.3 \\
\hline 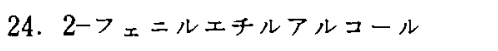 & 47.8 & 37.0 & 50.4 & - & 123.3 & - \\
\hline 25. ベンジルシア $=$ ド & - & - & - & - & 74.7 & - \\
\hline $\begin{array}{l}\text { 26. シスージャスモン } \\
\text { 27. } \beta \text {-ヨノン }\end{array}$ & 149.6 & 78.1 & 132.0 & 118.0 & 127.7 & 123.0 \\
\hline 28. ネロリドール & 207.1 & 171.2 & 487.5 & 520.4 & 1067.6 & 174.9 \\
\hline 29. ジャスミンラクトン & 38.8 & 46.8 & 172.9 & 161.7 & 125.3 & 49.7 \\
\hline 30. インドール & 29.2 & 24.7 & 123.5 & 290.4 & 155.5 & 20.6 \\
\hline 全精油量（mg/100 g 茶） & 27.7 & 24.2 & 34.3 & 28.0 & 40.6 & 34.4 \\
\hline
\end{tabular}

数値は，(全精油量） $\times$ (分析した全ピーク面積百分率) 
仙茶のそれぞれ一級品の仕上げ茶の香気成分分析の 結果から，前者の擋拌萎调法では，ネロリドール， フェニルアセトアルデヒド, リナロール，インドー ル等のスズランの花や果物のような香気成分を形成 し, 後者の日干萎调法では, ベンジルアルコール， ゲラニオール，2,5及び 2,6-ジメチルピラジン等の バラのような香りや甘い柔らかな香りのする成分の 形成は優れていると思われる。日干萎调も擋汼萎调 も花のような香りの形成には必要な処理であるが， 高沸点香気成分の形成には，擋䢁萎调の方が日干萎 调よりも良いよらである。

またこれらの結果には品種による差異もあると 考えられるが，どのような品種があるかは未確認で ある。しかし，それぞれの地域の茶樹に最も適した 萎调方法が採用されているものと思われる。

\section{2 茶の生産地と各種香気成分含量の差異}

同じ萎调法で製造した茶でも，その生産地の違い によって，香気成分含量は異なっていた。

一級品の鉄観音茶と永春水仙茶はともに南部福建 省の茶であるが，表に示してある通り，午の精油量 は, 前者が $40.6 \mathrm{mg} / 100 \mathrm{~g}$ 茶であるのに対して, 後 者は $27.7 \mathrm{mg} / 100 \mathrm{~g}$ 茶であり, 官能的にも前者の香 りは後者に比べて大变強い。

鉄観音茶の香気成分の中で，ネロリドール，ジャ スミンラクトン, 2-フェニルェチルアルコール, イ ンドール等の含量は, 永春水仙茶に比べて多く, ま た, ベンジルシアニドは, 表中の 6 種類の茶の中で は，鉄観音茶のみに含まれていた。

全精油量に対するネロリドールの比率が永春水仙 茶や鉄観音茶で異なるように，GC 分析で得られた 香気成分含量比率の違いによって，例兄ば永春水仙 茶の強く甘い, そして味わいのあるといった香りの 特徵が作られるものと思われる。

このよらに, 萎调方法が同じでも，生産地の違い によりその香りの特徵が異なるのは, 気候風土, 品 種等による様々な香気成分含量の違いや精油の中に 含まれるネロリドール等の主成分の相対含量が異な るためと推定した。

\section{3 荒茶と仕上げ茶の香気成分の差異}

同じ茶生産地の茶でも, 荒茶と仕上げ茶の香気成 分含量の間には違いがみられる。永春水仙茶の一級 品と二級品の, それぞれ荒茶及び仕上げ茶を比較し た結果によると，荒茶の全精油量は，一級品，二級 品とも仕上げ茶のものより多く、ネロリドール, ジャ スミンラクトン，インドール等の成分含量は荒茶に
多く，2,5及び 2,6-ジメチルピラジンとシスー3-へ キセニルアセテートは仕上莯では検出できなかっ た。この事実は茶を仕上げる最終段階で, 香気の大 きな変化が起こることを示している。長時間をかけ て再製し，揮発性成分が発散し易い精製工程が終わ った仕上げ茶では，その全精油量は減少し，各々の 香気成分含量も変化して，その結果，より柔らかな 味わいのある香りになる。同じ茶産地の荒茶と仕上 げ茶間の香気の特徵の違いは,これらの種々の香気 成分含量の変化によることが明らかとなった。

\section{4 茶のグレードの違いによる種々の香気成 分含量の比較}

官能検查により評価された同じ茶生産地のグレー ドの違ら茶は, 種々の香気成分の含量に違いがみら れた。

永春水仙茶の一級品と二級品の荒茶及び仕上げ茶 の香気成分を比較した結果によると，そ㧈ぞれの全 精油量は, 仕上げ茶, 荒茶の両方とも，一級品が二 級品よりる多く, 仕上げ茶, 荒茶に関俰なく, 官能 検査により高いグレードに評価された茶ほど，その 全精油量と高沸点の香気成分含量が多くなる傾向が あることが分かった。

\section{4 摘要}

6 種類の福建省産鳥竜茶の香気成分をガスクロマ トグラフ及びガスクロマトグラフー質量分析計で分 析し，その中から同定した代表的な 30 の香気成分 を比較した。

その結果, 福建省の南部の擋抖萎调と北部の日干 萎调を主体とした製茶法の中の萎调法の違いによ り, 各種香気成分の生成量が異なっており, 南部福 建省で行われている萎调法の方が，高沸点成分を含 む香気の形成には有利であった。

同じ茶産地の荒茶と仕上げ茶の問でも，その香気 を構成する香気成分に違いが見られ，一級品及び二 級品の荒茶の全精油量はそれぞれの仕上げ茶よりも 多く，大きな変化が仕上げ工程で起こった。

同じ茶生産地に属していても，官能的に違ったグ レードに評価された茶はその香気を構成する香気成 分に違いがあった。一級品の荒茶及び仕上げ茶は， それぞれの二級品の茶に比へて全精油量が多く，ま た，高沸点の香気成分含量も高かった。

\section{6 引用 文 献}

1）茶の生物学：安徽農科大学出版, $120 \sim 145$ 
(1979).

2）茶の化学のトピックス：安徽農科大学出版, 第 1 巻, $44 \sim 45$ (1984).

3）竹尾忠一：日食工誌, 28, 8〜12（1981）.

4) 竹尾忠一: 茶技研, No. 65, 1 12 (1983).

5) Yamanishi, T, M. Kosuge, Y. ToKitomo and R. MAEDA ; Agric. Biol. Chem ; 44, 2139 2142 (1980).

6）川上美智子, 小林彰夫, 山西 貞, 将積祝子: 農化，61，457４65（1987）.

7）堀田 博, 原 利男: 茶技研, No. $66,41 \sim 46$ (1984).

\section{Summary}

GC and GC-MS analysis were performed on six kinds of selected Fujian oolong teas and thirty major components identified were analyzed.

There were many differences in volatile components and their relative contents depending on the different tea processing techniques between southern and northern Fujian, rub-withering technique of the oolong tea in southern Fujian and sun-withering technique of the oolong tea in northern Fujian. The results indicated that rub-withering was more helpful to the formation of volatile components of higher boiling points.

There existed differences in the relative content of volatile components between rough and refined teas of the same tea cultivar. Both the first and the second classes of rough tea have larger quantity of total essential oil than the respective classes of refined tea and rather large changes are taken place in the process of refinement.

Different grades of tea of the same cultivar, evaluated by sensory test, have different content of volatile components. The contents of the total essential oil and volatile components of high boiling points of the first class teas were higher than that of the second class teas in both rough and refined teas.

(June 13, 1988). 